\title{
Twenty-First Century Conservation in Africa: Contemporary Dilemmas, Future Challenges
}

\author{
Michael Bollig
}

\begin{abstract}
Africa has been at the receiving end of the monikers of others, from the pejorative 'dark' continent of the 19th century to be labelled more recently, first, as 'hopeless' and then, a decade later, as 'rising' by The Economist. It's high time for Africa to carve out its own epithet. The Conservation Continent is a positive option for many good reasons. DESALEGN ET AL. 2020
\end{abstract}

African wildlife and wilderness landscapes play an outsized role in global schemes for biodiversity protection and adaptation to climate change. If terrestrial protected areas are expanded worldwide, as is emphatically demanded by many contemporary commentators on the current crises, a major part of this expansion will occur - and indeed is already taking place - on the African continent. Is Africa on its way to becoming the 'conservation continent', as the introductory quote by Desalegn et al. (2020) suggests?

A few brief points must suffice to illustrate the contemporary social-ecological crisis. A World Bank communication estimates that climate change alone will result in the loss of over half of African bird and mammal species by $2100 .{ }^{1}$ Habitat loss and landscape fragmentation due to agricultural intensification, and the expansion of agricultural activities conditioned by growing population numbers, is an important driver for biodiversity loss (Perrings and Halkos 2015) and biological annihilation (Ceballos et al. 2017). Rivers have been progressively impounded for hydroelectric use, causing large-scale ecological changes in aquatic biodiversity (Mahe et al. 2018). Rapid deforestation linked to agricultural encroachment, and increasing commercial logging, is

1 https://www.worldbank.org/en/news/feature/2019/o2/14/biodiversity.

(C) MICHAEL BOLLIG, 2022 DOI:10.1163/9789004471641_010

This is an open access chapter distributed under the terms of the CC BY-NC 4.0 License. 
significant in many African countries. The explosion of invasive species is displacing indigenous animal and plant species in all biomes across the continent (Seebens et al. 2020; UNEP 2016). The rapid growth of agro-industrial estates is a further driving force for habitat change (Batterbury and Ndi 2018; Mulubrhan 2015). Violent conflicts in many contexts have contributed to habitat destruction, biodiversity decline, and species extinction (Brito et al. 2018; de Merode et al. 2007).

So much for the doom scenario! There is another view on African nature that conveys hope and inspiration for a more convivial form of multispecies existence: more than half the world's unconverted arable land lies in Africa, indicating broad prospects for both food production and conservation (UNEP 2016: 37 ). In the early twenty-first century, about 4.28 million square kilometres, or 14.2 per cent of the continent's terrestrial surface, were demarcated as biodiversity preserves (cf. Europe 3.18 million square kilometres, or 11.4 per cent). Across the continent, more than 8448 protected areas, including about 1100 national parks (of which 36 have been enshrined as World Heritage sites) have increased the chances of survival for many species, while significantly altering human-environment relations. In a number of places, particularly in southern Africa, increases in wildlife populations and attempts to refaunate landscapes are readily observable (see Stoldt et al. 2020 on northeastern Namibia). The expansion of protected areas is spectacular if we consider the percentage of land under protection in single African countries - in Namibia 38 per cent, Botswana 29 per cent, Zimbabwe 27 per cent, Zambia 41 per cent, and Tanzania 38 per cent (all figures UNEP-WCMC 2020).

It is highly likely that the percentage of protected areas will grow further: many states worldwide, and most African states, have signed the Nagoya Protocol and its Aichi targets stipulating that 17 per cent of all terrestrial systems should be protected by 2020 (https://www.cbd.int/sp/targets) - apparently many African signatories reached that target well before the intended date. Some visions go far beyond what has been agreed upon in the Aichi Protocol. The widely circulated Half Earth Initiative (Wilson 2016) argues that we will only be able to halt species extinction effectively if we set aside about half of the Earth's surface for protection. Baillie and Zhang (2018) suggest that the Convention on Biological Diversity should stipulate that 30 per cent of ocean and terrestrial systems should be protected by 2030 , and $5^{\circ}$ per cent by $205^{\circ}$. They conclude that "anything less will likely result in a major extinction crisis and jeopardize the health and well-being of future generations" (Baillie and Zhang 2018: 1051). Dinerstein et al. (2019) promote a Global Deal for Nature and combine it with planning promulgated by the Paris Climate Agreement. They argue that, to achieve the Paris agreement goal to stay below $1.5^{\circ} \mathrm{C}$ warming, 
30 per cent of the Earth will need to be formally protected and an additional 20 per cent designated as climate stabilization areas by 2030. The maps in Dinerstein et al. (2019) show that Africa will be crucial to such efforts of global environmental planning.

There are very different visions about how these goals can be accomplished. While neo-protectionists argue for an expansion of land exclusively held in preservation, neo-conservationists argue for an integration of human land use and conservation (see Büscher and Fletcher (2020) for an excellent critical summary of both trajectories). Neo-protectionists emphasize that only a significant reduction of land use will at least slow down current rates of species extinction (Wilson 2016). They are prepared to embrace economic losses (mainly in the biodiversity hot spots of the world) and argue that nature needs to be saved from the vagaries of capitalist accounting. In contrast, Kareiva et al. (2012) argue that such "protected areas will remain islands of 'pristine nature' in a sea of profound human transformations to the landscape" and that integrative and patchy working landscapes of conservation are thus the best option (Kremen and Merenlender 2018). Advocates of the working landscapes approach argue that the integration of global commodity chains geared towards sustainable land use open new perspectives for conservation.

Both directions are gaining momentum in the second decade of the twentyfirst century. Parks into which people recently migrated have been refurbished for example in Chad and Zimbabwe and rendered into new fortresses of conservation. Surveillance is stepped up and, in many cases, militarized (Duffy et al. 2019). At the same time, efforts to establish working conservation landscapes in numerous community-based projects increase with enormous international efforts focused on buffer zones around protected areas, including the corridors connecting them.

\section{National Parks: Emergence, Stabilization and Critique of the 'Fortress' Paradigm}

Game reserves have been founded in sub-Saharan Africa since the beginning of the twentieth century (Anderson and Grove 1986). MacKenzie (1988: 261-77) has sketched the transition from hunting reserves to national parks since the 1930s, emphasizing a fundamental shift in perspective: while hunting reserves were established by proclamation or ministerial decree, and could be deproclaimed at any time, national parks were established in perpetuity and were based on fully-fledged legislation. Accordingly, park management 
was separated from other aspects of government administration - sometimes a state within the state, with its own territory, laws, and administration. National parks were meant for tourism and, from the outset, were thought to be self-financing (MacKenzie 1988: 264). Accordingly, they were fitted with infrastructure, roads, lodges, and camp grounds - human-made and planned wildernesses suitable for consumption. For an excellent case study, see Carruthers (1995) on South Africa's Kruger National Park. While early on, indigenous communities, foragers, and pastoralists were permitted within national parks after the 1950s wildlife conservation and human land use were perceived as incompatible. This resulted in further dislocations, and the removal of entire communities from these emergent fortresses of conservation. For example, see Dieckmann (2007) on the removal of the Haillom San from Etosha National Park in Namibia, and Reid (2012) on the removal of Maasai from conservation areas in Tanzania and Kenya.

There is an enormous amount of literature on the malign social consequences of 'fortress conservation' (Brockington 2002). Poverty, marginalization, and exposure to human-wildlife conflict are commonplace in the buffer zones around national parks. Brockington and Igoe (2006) analysed 250 reports on relocations from 18 o conservation areas, 60 of them from southern and eastern Africa. They show that forced relocations, for example, in sub-Saharan Africa, climaxed in the 1960s and 1970s, namely, during the first two decades of independence for many African countries (Brockington and Igoe 2006: 440). The fortress conservation approach remained unquestioned for several decades, promising international tourism and global attention. The crises of national parks in many African countries in the 1980s and 1990s - weak governance, negligible economic returns from tourism, poaching, often connected to violent conflict and economic demise (Lewis 1996) - led to a reconsideration of protected-area politics across the continent.

\section{Privatization and Globalization of Protected Areas}

Private donors have invested extensively in African national parks in recent years. Adams (2019) reports that Mozambique's Gorongoza Park experienced more than a 700 per cent increase in its wildlife population from a decade ago, after the foundation of US American philanthropist Gregory Carr spent nearly US $\$ 6$ o million on park management and on socio-economic development in surrounding buffer zones since 2008. Carr's organization received tenure of the park from the Mozambiquan government for a number of decades. Gorongoza is not a singular case: philanthropic engagement in African parks 
is frequent and certainly increasing, as Ramutsindela et al. (2011) and Spierenburg and Wels (2010) have shown.

Another model of organizational reform for protected area governance has been developed by African Parks, a highly specialized NGO that organizes park management on behalf of national authorities and is backed with massive international funding. Today, African Parks has a portfolio of fifteen parks in nine African countries. For these parks, the NGO holds management contracts of twenty or more years. African Parks has a comprehensive mandate: in protected areas, it is responsible for both the tourism infrastructure and for the public infrastructure in surrounding buffer zones. Law enforcement also falls under its mandate, as it coordinates armed anti-poaching units. They may arrest people to hand over to the police later, and they may shoot in self-defence. ${ }^{2}$ African Parks also runs refaunation projects in depleted protection areas; for example, it relocated black rhinos from South Africa to Chad's Zakouma Park.

African Parks is supported by a vast and intransient range of north American and European philanthropic organizations, as well as the National Geographic Society, the European Union, the Wildcat Foundation and WwF, the US Fish and Wildlife Service, and the US Forest Service. The website also lists organizations as diverse as the Dutch Postcode Lottery, the Department for International Development (DFID), and various African governmental authorities, such as the Zambian Department of National Parks and Wildlife, traditional authorities such as the Barotse Royal Establishment of Zambia, and less transient funds, such as the Adessium Foundation and the hedge fund, Acacia Conservation Fund (Offshore), Ltd. Such funding networks invite questions of responsibility and accountability, let alone democratic legitimization and control (see Sullivan 2012).

While African Parks runs the management of protected areas on its own, and is backed by a great number of highly diverse international funders, the Frankfurt Zoological Society (FZs) developed a business and management model that tends more towards cooperation. In 2007, Zimbabwe Parks 'invited' FZs to support Gonarezhou National Park, Zimbabwe's share of the giant Limpopo Transboundary Park. Fzs was instrumental in developing a ten-year management plan in a comprehensive stakeholder process. The plan entailed the establishment of the Gonarezhou Conservation Trust, which has a mandate to assume all management responsibilities from March 2017 onwards. The trust is directed by a board of six trustees, nominated in equal numbers by ZimParks

2 https://www.africanparks.org/about-us/our-story. 
and FzS. The FzS runs similar projects in Tanzania and Zambia, where, for example, the North Luangwa National Park is managed along similar lines.

Privatization and internationalized partnerships for the governance of protected areas often imply a return to fortress conservation (Scoones 2020). An increasingly militarized approach towards controlling poachers is linked to efforts to control the park boundaries. The International Anti-Poaching Foundation, for example, is financing the training of rangers in Zimbabwe, and the Frankfurt Zoological Society is sponsoring the construction of an electric fence around Gonarezhou National Park (Scoones 2020). There are certainly community projects occurring near these protected areas, but as Scoones (2020) reports for Zimbabwe, there are numerous reasons why these projects are ineffective and address problems such as human-wildlife conflict only in a haphazard way.

Transboundary conservation areas that aggregate conservation areas with different legal statuses across international boundaries are yet another approach to expanding the reach of protected areas. Transboundary conservation areas have especially gained ground in southern Africa. For example, the Kavango-Zambezi Transfrontier Conservation Area (KAZA) with 520,000 square kilometres of land, and the Greater Limpopo Transboundary Park with 35 ,ooo square kilometres of land (with current plans to expand it to nearly 100, ooo square kilometres), have gained the status of the world's largest contiguous conservation areas. In both transboundary conservation areas, existing national parks, protected forests, and community conservation areas have been fused. In such transnational conservation areas, administrations combine their efforts to guarantee the connectivity of protected lands and the mobility of species, and to increase their attractiveness for tourists (Barrett 2013). Efforts aimed at creating more connectivity across international boundaries for wildlife, however, only rarely imply a similar freedom of movement for local people.

As in the examples given above on the privatization and outsourcing of governmental services, the influence of international donors and international NGO s is major. The South Africa-based Peace Parks Foundation has been the driving force behind transboundary conservation projects, conveniently highlighting their contribution to conservation, development, and peaceful transboundary relations. The Peace Parks Foundation is funded by a vast array of international funders, ranging from De Beers and Anglo American (both multinational mining companies) to the US International Bureau of Narcotics and Law Enforcement Affairs. Whether conservation gigantism has sizeable socioecological effects is not yet clear, although recent research points to increased mobility of large herbivores and the refaunation of wildlife-poor landscapes through immigration from areas with high wildlife numbers (see, for example, 
Brennan et al. 2020; Stoldt et al. 2020). But transboundary conservation has also been blamed for expanding the fortress conservation approach, and further sidelining communities living in long-marginalized areas (Ramutsindela 2018; van Amerom and Büscher 2005).

Figures given by the World Database of Protected Areas (UNEP-wCMA 2020) reflect this heterogeneity of protected area governance only to some extent. Of 8448 protected areas counted in Africa, 3710 are managed by federal or national ministries and 986 by sub-national ministries. For a staggering 2351 of the protected areas, governance is not reported adequately. Some 933 protected areas are private (mainly in South Africa), only 69 are managed collaboratively between government and other agencies, 30 are governed by non-profit organizations, and another 30 by indigenous communities (a good number of them conservancies in Kenya). There is little conclusive reporting within this dataset on conservation governance for numerous countries. No governance types are reported for protected areas in Zimbabwe, as well as Chad, Angola, or the Central African Republic. For Zambia, no governance type is reported for more than 90 per cent of protected areas, and there is no reporting for 267 out of 409 protected areas in Kenya. By contrast, governance types are reported for 819 out of 838 protected areas in Tanzania. If we temporarily focus on Tanzania for the completeness of reporting in this regard, we may conclude that governmental ministries in Tanzania are still in the driver seat (774 protected areas are governed by the appropriate ministry), by contrast with several other African countries (notably, those where reporting is inconsistent), where much responsibility has been delegated to external organizations. Generally, the aggregate data are insufficient to facilitate an assessment of governance across the continent. Reports from various websites, however, suggest a wide variety of governance styles in a good number of countries, increasing influence of international organizations running protected areas, growing significance of philanthropic capital, and the engagement of large international companies and banks. Protected areas are increasingly being run according to very different management models. These come with different ideas about what is to be protected, about refaunation and rewilding, and about participation. Increasingly, national parks are becoming international, intransient multi-stakeholder enterprises, and are therefore extremely difficult to control or hold accountable. In many ways, national parks are becoming international parks.

In the 1980s, fortress conservation began to come under heavy criticism. Fortified islands of conservation did not automatically result in species survival and 
biodiversity protection. In fact, they failed to yield anticipated conservation results and instead brought rampant poaching. These observations led to the conclusion that those communities affected by conservation measures needed to be included in planning and practice to maintain protected buffer zones and create wildlife corridors. Further, the direct participation of local people in the economic gains of conservation were thought to be necessary to gain the cooperation and compliance of rural communities directly affected by conservation. Community-based conservation (СвС) programmes thus became a dominant paradigm in the 199os, and have remained prominent in various forms of conservation to this day (Berkes 2007; Galvin et al. 2018). In Africa, СвС programmes gained currency in southern and eastern Africa, but less so in central and western Africa. What community-based conservation exactly entailed differed across sub-Saharan Africa. In many places, СвС was implemented as community-based natural resource management (CBNRM), which was also shaped by programmes, projects, and legislation, for example, for forestry and water management. Generally, CBNRM meant "local groups of people ('communities') managing resources in an active manner and with some significant degree of formal (de jure) or informal (de facto) control or tenure over those resources" (Roe et al. 2009: 13). СвС projects linked conservation with development, sought to engage local communities as active stakeholders, and devolved some control over natural resources (Brooks et al. 2012). This conformed with neoliberal approaches to conservation, which stipulated that the commodification of wildlife and landscapes, and the inclusion of rural citizens into global value chains, could become a significant motor for both conservation and rural development. In francophone West Africa, the term CBNRM was and still is employed in a rather spatialized sense, and policies refer to ' $C B N R M$ zones' or 'СвNRM corridors'. In East Africa, community-based conservation also had its start in buffer zones around national parks and private conservation areas. Protected-area outreach and benefit sharing were crucial for early East African СвС programmes. Recently, however, East African СвС projects have demanded more power in participating in decision-making regarding wildlife and other natural resources (Mkutu and Mdee 2020). Only in southern Africa (notably, in Namibia, Zambia, Botswana, and Zimbabwe) has свс been closely connected to decentralization and the devolvement of rights - to natural resources in general, and wildlife in particular - to rural communities (for example Bollig and Menestrey Schwieger 2014).

In a recent study, Galvin et al. (2018) analysed the social, economic, and ecological outcomes of СвС in sub-Saharan Africa. The authors summarize that "more often than not, [the] establishment of свС in Africa has led to negative or a mixture of positive and negative outcomes, whereas the ecological 
outcomes have been largely positive" (Galvin et al. 2018: 39). Positive social outcomes pertained predominantly to increased income and human capital, whereas negative ones were related to the unequal distribution of benefits and reduced social capital. Positive social outcomes relating to financial income were habitually connected to direct payment schemes, which included cash dividends as a portion of visitor levees or lease agreements. They were also "associated with the maintenance and enhancement of networks, relationships of trust, reciprocity and exchange, and [an] increased sense of ownership among СвС members for conservation-oriented projects" (Galvin et al. 2018). Negative outcomes commonly pertained to an unequal distribution of benefits, elite capture, erosion of community trust, frustration in cases where distributive mechanisms were not working well, and the breakdown of traditional land tenure institutions. Comparing a total of 136 свС projects worldwide, Brooks et al. (2012) emphasize that project design and capacity building, in particular, are associated with the success of свС projects. True participation of locals in the implementation and day-to-day management of projects, equity in benefit distribution, and improvement of human and social capital are of crucial importance for success. Interestingly, Brooks et al. find that ecological and economic success are frequently interrelated, and that the success of СвС projects is more closely associated with project design than with community characteristics. Oldekop et al. (2016) show that the best predictor for the ecological success of conservation projects were positive socioeconomic outcomes, implying the establishment of co-management regimes, the empowerment of local people, the reduction of economic inequalities, and the maintenance of cultural and livelihood benefits. Moreover, СвС projects are progressively characterized by a large number of interacting stakeholders seeking to produce conservation results. Berkes (2007:15190) suggests that CBC projects typically involve a rural community together with ten to fourteen partners, including national and international NGO s, private enterprises, and governmental offices. What is protected, how it is protected, and how conservation governance operates is a matter of lengthy negotiations (see Bollig (2020) for an example from northwestern Namibia).

With communities idealized and intra-community cleavages and inequalities disregarded in planning, there are as many critiques of СвС projects as of fortress conservation. Often, neoliberal approaches to СвС exacerbate existing inequalities and wealthy households are more likely to gain from it than poorer ones (Holmes and Cavanagh 2016: 205). For KAZA and its related Namibian conservancies, Kalvelage et al. (2020) have shown that the cumulative benefits for community-based conservancies are sizeable, but that the sheer amount of income does not say anything about its distribution. In many 
national contexts, the devolvement of rights is contested, as administrations frequently fail to cede their prerogatives voluntarily. Moreover, attempts to secure economic success are often futile: the commodification of wildlife and wilderness, and the public-private partnerships linked to it, frequently do not yield the promised or envisaged results. Rural dwellers often end up burdened with sizeable costs resulting from human-wildlife conflict, frustrations about elite capture, and fraud and conflicts over access to natural resources (Gargallo 2015; Holmes and Cavanagh 2016; Schnegg and Kiaka 2018; Sullivan 2006). Many discussions centre on whether trophy hunting and tourism in СвС areas are the most viable ways of providing income to rural communities and alleviating poverty (see Koot et al. 2020; Naidoo et al. 2018). Certainly, seeing the СвС programmes heralded in the 198 os and 199os as the most promising way of combining conservation, economic development, and participation requires in-depth and comparative scrutiny. СвС will need a pro-poor component to address poverty, perhaps best achieved through cash transfers coupled with settlement rights in a conservation area. Another unresolved issue is how to deal with human-wildlife conflict and substantial damages caused by increasing numbers of wildlife, despite a small number of promising compensation programmes. СвС programmes will also need more businesses to be directly owned and run by local entrepreneurs. A near complete dependence on jointventure capital and expertise will be detrimental in the long run. The recent COVID-19 crisis shows that an over-reliance on tourism carries specific risks (Lendelwo and Sullivan (2020) for Namibia).

\section{5}

\section{Conclusion}

Where do we go from here? Protected areas will expand: all political agreements, economic considerations, and much-highlighted contemporary global challenges - like biodiversity loss and climate change - unequivocally point in this direction. The expansion of protected areas is also in the interest of states even if they do not intend to manage such areas on their own. Protected areas guarantee continued interest by international donors and the constant flow of finances to the country. To prevent the expansion of protected areas from going against the interests of rural communities, such transfers require corporate social responsibility regulations that are internationally supervised. Moreover, investments in conservation and transnational governance of subSaharan conservation areas are in urgent need of increased transparency, accountability, and comprehensive considerations of environmental justice. 
The ongoing sense of crisis and reporting on impending biodiversity collapse and mass extinctions often make us forget that these governance values constitute the basis of successful natural resource management and are not merely nice assets to have. Büscher and Fletcher (2020) present an agenda for convivial conservation beyond conventional nature/culture dichotomies, and beyond a capitalist mode of production, by abstaining from commodifying nature or seeking ecological redemption in the growth of conservation markets. While this may take time to come about, the short-term measures envisaged by proponents of convivial conservation may be of considerable importance for the coming decades; these include historic reparations for people's loss of land and livelihood opportunities within protected areas; conservation-related basic incomes to promote decent livelihoods for those living in or close to protected areas; re-evaluating relationships with corporations and major conservation NGOs; implementing democratic conservation governance, and identifying alternative funding mechanisms (Büscher and Fletcher 2020: 186-97). It is high time to test-run such approaches and to refine ways of governing and protecting resources in an equitable, just, and sustainable manner, as contemporary challenges are formidable and will require global efforts. The challenge of establishing socio-ecological conditions for the flourishing of all lifeworlds in the twenty-first century will only stand a chance if these fundamentals of environmental justice are established.

\section{References}

Adams, P. 2019. "A comeback for African national parks." New York Times, 20 February. Anderson, D. and R. Grove. 1986. Conservation in Africa: People, policies and practice. Cambridge: Cambridge University press.

Baillie, J. and Y. Zhang. 2018. "Space for nature." Science, 361: 1051. DoI: 10.1126/science. aaur397.

Barrett, G. 2013. "Markets of exceptionalism: Peace parks in southern Africa." Journal of Contemporary African Studies, 31, 3:457-480.

Batterbury S. P. J. and F. Ndi. 2018. "Land grabbing in Africa." In The Routledge handbook of African development, edited by J. A. Binns, K. Lynch and E. Nel, 573-582. London: Routledge.

Berkes, F. 2007. "Community-based conservation in a globalized world." PNAS, 104, 39: 15188-15193.

Bollig, M. 2020. Shaping the African Savannah: From capitalist frontier to arid Eden in Namibia. Cambridge: Cambridge University Press. 
Bollig, M. and D. A. Menestrey Schwieger. 2014. "Fragmentation, cooperation and power: Institutional dynamics in natural resource governance in north-western Namibia." Human Ecology, 42, 2: 167-181.

Brennan A., P. Beytell, O. Aschenborn, P. Du Preez, P. J. Funston, L. Hanssen, et al. 2020. "Characterizing multispecies connectivity across a transfrontier conservation landscape." Journal of Applied Ecology, 57, 9: 1700-1710.

Brito, J., S. Durant, N. Pettorelli, S. Canney, et al. 2018. "Armed conflicts and wildlife decline: Challenges and recommendations for effective conservation policy in the Sahara-Sahel." Conservation Letters, 11, 5: e12246. DOI: 10.1111/conl.12446.

Brockington, D. 2002. Fortress conservation: The preservation of the Mkomazi Game Reserve. Oxford: James Currey.

Brockington, D. and J. Igoe. 2006. "Eviction for conservation: A global overview." Conservation and Society, 4, 3: 424-470.

Brooks, J. S., K. A. Waylen and M. Borgerhoff Mulder. 2012. "How national context, project design, and local community characteristics influence success in communitybased conservation projects." PNAS, 109, 52: 21265-21270.

Büscher, B. and R. Fletcher. 2020. The conservation revolution. Radical ideas for saving nature beyond the Anthropocene. London: Verso.

Carruthers, J. 1995. The Kruger National Park: A social and political history. Pietermaritzburg: University of Natal Press.

Ceballos, G., P. Ehrlich and R. Dirzo. 2017. "Biological annihilation via the ongoing sixth mass extinction signaled by vertebrate population losses and declines." PNAS, 114, 3०: E6o89-E6o96.

de Merode, E., K. Hillman Smith, K. Homewood R. Pettifor, M. Rowcliffe and G. Cowlishaw. 2017. "The impact of armed conflict on protected area efficacy in Central Africa." Biological Letters, 3, 3: 299-301.

Desalegn, H., M. du Toit and G. Mills. 2020. "Why Africa must become the conservation continent." Daily Maverick, 22 July. https:/www.dailymaverick.co.za/article/2020 -07.22-whv-africa-must-become-the-conservation-continent/.

Dieckmann, U. 2007. Hai//om in the Etosha Region: A history of colonial settlement, ethnicity and nature conservation. Basel: Basler Afrika-Bilbliographien.

Dinerstein, E., C. Vynne, E. Sala, A. R. Joshi, S. Fernando, T. E. Lovejoy, J. Mayorga, et al. 2019. "A global deal for nature. Guiding principles, milestones, and targets." Science Advances, 5, 4: DoI: 10.1126/sciadv.aaw2869.

Duffy R., F. Massé, E. Smidt, E. Marijnen, B. Büscher, J. Verweijen, M. Ramutsindela, T. Simlai, L. Joanny and E. Lunstrum. 2019. "Why we must question the militarization of conservation." Biological Conservation, 232: 66-73.

Galvin, K., T. Beeton and M. Luizza. 2018. "African community-based conservation: A systematic review of social and ecological outcomes." Ecology and Society, 23, 3: 39. DOI: $10.5751 /$ ES-10217-230339. 
Gargallo, E. 2015. "Conservation on contested lands: The case of Namibia's communal conservancies." Journal of Contemporary African Studies, 33, 2: 213-231. DoI: 10.1080/02589001.2015.1065575.

Holmes, G. and C. J. Cavanagh. 2016. "A review of the social impacts of neoliberal conservation: Formations, inequalities, contestations." Geoforum, 75: 199-209.

Kalvelage, L., J. Revilla-Diez and M. Bollig. 2020. "How much remains? Local value capture from tourism in Zambezi, Namibia." Tourism Geography, DoI: 10.1080/14616688.2020.1786154.

Kareiva P., R. Lalasz and M. Marvier. 2012. "Conservation in the Anthropocene: Beyond solitude and fragility." Breakthrough Journal, 1 February. https://thebreakthrough .org/journal/issue-2/conservation-in-the-anthropocene.

Koot, S., P. Hebinck and S. Sullivan. 2020. "Science for success - a conflict of interest? Researcher position and reflexivity in socio-ecological research for CBNRM in Namibia." Society \& Natural Resources, DOI: 10.1080/o8941920.2020.1762953.

Kremen, C. and A. M. Merenlender. 2018. "Landscapes that work for biodiversity and people." Science, 362, 6412. Do I: 10.1126/science.aau6o20.

Lendelvo, S. and S. Sullivan. 2020. "A perfect storm? The impact of CoviD-19 on community-based conservation in Namibia." Namibian Journal of Environment, 4: $1-15$.

Lewis, P. 1996. "Economic reform and political transition in Africa: The quest for a politics of development." World Politics, 49, 1: 92-129.

MacKenzie, J. 1988. The empire of nature. Hunting, conservation and British imperialism, Manchester: Manchester University Press.

Mahe G. et al. (2018) "Assessment of the impact of dams on river regimes, sediment transports to the sea, and coastal changes." In Recent advances in environmental science from the Euro-Mediterranean and surrounding regions, edited by A. Kallel, M. Ksibi, M. Ben Dhia and N. Khélifi, 31-32. Cham: Springer.

Mkutu, K. and A. Mdee. 2020. "Conservancies, conflict and dispossession: The winners and losers of oil exploration in Turkana, Kenya." African Studies Review, 63, 4: 831-857. DOI: $10.1017 /$ asr.2020.2.

Mulubrhan B. 2015. "Unintended consequences: The ecological repercussions of land grabbing in sub-Saharan Africa." Environment: Science and Policy for Sustainable Development, 57, 2: 4-21, DOI: 10.1080/oo139157.2015.1001687.

Naidoo, R., J. W. Kilian, P. du Preez, P. Beytell, O. Aschenborn, R. D. Taylor and G. StuartHill. 2018. "Evaluating the effectiveness of local- and regional-scale wildlife corridors using quantitative metrics of functional connectivity." Biological Conservation, 217: $96-103$.

Oldekop, J. A., G. Holmes, W. E. Harris and K. L. Evans. 2016. "A global assessment of the social and conservation outcomes of protected areas." Conservation Biology, 3०, 1: 133-141. 
Perrings, C. and G. Halkos. 2015. "Agriculture and the threat to biodiversity in subSaharan Africa." Environmental Research Letters, 10, 9. DOI: 10.1088/1748-9326/ 10/9/095015.

Ramutsindela, M. 2018. Remapping Africa through peace parks: What future for the continent? Inaugural Lecture at the University of Cape Town. http://www.science.uct. ac.za/news/peace-parks-how-green-map-africa-evolving [30 June 2020].

Ramutsindela, M., M. Spierenburg and H. Wels. 2011. Sponsoring nature. Environmental philanthropy for conservation. London: Routledge.

Reid, R. 2012. Savannas of our birth: People, wildlife, and change in East Africa. San Francisco: University of California Press.

Roe, D., F. Nelson, C. Sandbrook (Eds). 20o9. Community management of natural resources in Africa: Impacts, experiences and future directions. Natural Resource Issues No. 18. London: IIED.

Schnegg, M. and R. Kiaka. 2018. "Subsidized elephants: Community-based resource governance and environmental (in)justice in Namibia." Geoforum, 93: 105-115.

Scoones, I. 2020. The return of fortress conservation: Why excluding people means biodiversity conservation will fail. Zimbabweland blog. 12 October. https://zimbabweland. wordpress.com/2020/10/12/the-return-of-fortress-conservation-why-excludingpeople-will-ensure-biodiversity-conservation-will-fail [13 October 2020].

Seebens, H., S. T. Becher, C. Blackburn, W. Capinha, S. Dawson, P. Dullinger, et al. 2020. "Projecting the continental accumulation of alien species through to 2050." Global Change Biology, 27, 5: 970-982. DoI: 10.1111/gcb.15333.

Spierenburg, M. and H. Wels. 2010. "Conservative philanthropists, royalty and business elites in nature conservation in southern Africa." Antipode, 42, 3: 647-670.

Stoldt, M., T. Göttert, C. Mann and U. Zeller. 2020. "Transfrontier conservation areas and human-wildlife conflict: The case of the Namibian component of the KavangoZambezi (KAZA) TFCA." Sci Rep, 10, 7964. DoI: 10.1038/s41598-o2o-64537-9.

Sullivan, S. 2006. "Elephant in the room? Problematising 'new (neoliberal) biodiversity conservation." Forum for Development Studies, 33, 1: 105-135.

Sullivan, S. 2012. "Banking nature? The spectacular financialisation of environmental conservation." Antipode, 45, 1: 198-217.

UNEP. 2016. Global environmental outlook 6: Regional assessments. Nairobi: UNEP.

UNEP-WCMC. 202O. Protected area profile for Africa from the World Database on Protected Areas. October. www.protectedplanet.net.

van Amerom, M. and B. Büscher. 2005. "Peace parks in southern Africa: Bringers of an African Renaissance?" Journal of Modern African Studies, 43, 2: 159-182.

Wilson, E. 2016. Half-Earth. Our planet's fight for life. London: Liveright. 